\title{
Clinical hypothermia temperatures increase complement activation and cell destruction via the classical pathway
}

Tushar A Shah ${ }^{1,3,4^{*}}$, Clifford T Mauriello ${ }^{1}$, Pamela S Hair ${ }^{1}$, Amandeep Sandhu ${ }^{2}$, Michael P Stolz ${ }^{1}$, William Thomas Bass ${ }^{1,3,4}$, Neel K Krishna ${ }^{1,2}$ and Kenji M Cunnion ${ }^{1,2,3,4}$

\begin{abstract}
Background: Therapeutic hypothermia is a treatment modality that is increasingly used to improve clinical neurological outcomes for ischemia-reperfusion injury-mediated diseases. Antibody-initiated classical complement pathway activation has been shown to contribute to ischemia-reperfusion injury in multiple disease processes. However, how therapeutic hypothermia affects complement activation is unknown. Our goal was to measure the independent effect of temperature on complement activation, and more specifically, examine the relationship between clinical hypothermia temperatures $\left(31-33^{\circ} \mathrm{C}\right)$, and complement activation.

Methods: Antibody-sensitized erythrocytes were used to assay complement activation at temperatures ranging from $0-41^{\circ} \mathrm{C}$. Individual complement pathway components were assayed by ELISA, Western blot, and quantitative dot blot. Peptide Inhibitor of complement C1 (PIC1) was used to specifically inhibit activation of C1.

Results: Antibody-initiated complement activation resulting in eukaryotic cell lysis was increased by 2 -fold at $31^{\circ} \mathrm{C}$ compared with $37^{\circ} \mathrm{C}$. Antibody-initiated complement activation in human serum increased as temperature decreased from $37^{\circ} \mathrm{C}$ until dramatically decreasing at $13^{\circ} \mathrm{C}$. Quantitation of individual complement components showed significantly increased activation of $\mathrm{C} 4, \mathrm{C} 3$, and $\mathrm{C} 5$ at clinical hypothermia temperatures. In contrast, $\mathrm{C} 1 \mathrm{~s}$ activation by heat-aggregated IgG decreased at therapeutic hypothermia temperatures consistent with decreased enzymatic activity at lower temperatures. However, C1q binding to antibody-coated erythrocytes increased at lower temperatures, suggesting that increased classical complement pathway activation is mediated by increased C1 binding at therapeutic hypothermia temperatures. PIC1 inhibited hypothermia-enhanced complement-mediated cell lysis at $31^{\circ} \mathrm{C}$ by up to $60 \%(P=0.001)$ in a dose dependent manner.

Conclusions: In summary, therapeutic hypothermia temperatures increased antibody-initiated complement activation and eukaryotic cell destruction suggesting that the benefits of therapeutic hypothermia may be mediated via other mechanisms. Antibody-initiated complement activation has been shown to contribute to ischemia-reperfusion injury in several animal models, suggesting that for diseases with this mechanism hypothermia-enhanced complement activation may partially attenuate the benefits of therapeutic hypothermia.
\end{abstract}

Keywords: Therapeutic hypothermia, Complement, Classical pathway, Complement inhibitor, Ischemia-reperfusion injury, Inflammation

\footnotetext{
* Correspondence: shahta@evms.edu

'Department of Pediatrics, Eastern Virginia Medical School, 855 West Brambleton Avenue, Norfolk, VA 23510, USA

${ }^{3}$ Children's Specialty Group, 811 Redgate Avenue, Norfolk, VA 23507, USA

Full list of author information is available at the end of the article
} 


\section{Introduction}

Therapeutic hypothermia improves neurological outcome in ischemia-reperfusion injury (IRI) caused by cardiac arrest [1], traumatic brain injury [2], stroke [3], acute liver injury [4] and neonatal hypoxic ischemic encephalopathy [5]. In addition to decreased cerebral metabolism [6], hypothermia appears to attenuate multiple processes that contribute to tissue damage following IRI including neuroinflammation [7], excitotoxicty [8], mitochondrial dysfunction [9], apoptosis [10], free radical production [11], seizure activity [12] and blood-brain barrier disruption [13]. Hypothermia is also purported to stimulate protective cold shock proteins [14].

The complement system is an extremely potent inflammatory cascade composed of more than 30 plasma and cell membrane proteins that plays major roles in innate immune defense as well as many inflammatory diseases including IRI. Clinical and experimental studies in multiple organ systems have shown that reperfusion following ischemia results in local activation of the complement system [15]. Complement activation in IRI is primarily mediated by circulating natural antibodies (IgM) binding to neo-antigens expressed on the surface of hypoxia-stressed endothelial cells leading to classical complement pathway activation or lectin pathway activation [16,17]. In addition to direct complement-mediated endothelial cell damage during reperfusion, complement induced neutrophil recruitment and activation causes significant injury through the phagocytic actions of macrophages, free radical production and synthesis of toxic products [8]. Complement inhibition has been shown to be protective in animal models of brain [18], kidney [19] and liver [20] IRI.

While several mechanisms of action for therapeutic hypothermia have been proposed, the effect of hypothermia on complement activation is unknown. Whether improved outcomes in IRI could be due, in part, to hypothermia inhibiting or attenuating complement activation has not yet been explored. Such a mechanism is plausible given that complement activation is enzymatic and slows down dramatically at very low temperatures of $0-4^{\circ} \mathrm{C}[21,22]$. However, whether the temperatures of clinical hypothermia, $31-33^{\circ} \mathrm{C}$, would inhibit complement activation remains untested. The increasing use of therapeutic hypothermia in the treatment of IRI diseases makes understanding the contribution of the complement system critical. These experiments elucidate how therapeutic hypothermia temperatures modulate antibody-initiated complement activation.

\section{Methods}

\section{Ethics statement}

Pooled normal human serum (NHS) was derived from the blood of healthy human volunteers obtained with written informed consent in accordance with an Institutional
Review Board approved protocol (IRB 02-06-EX-0216, Eastern Virginia Medical School).

\section{Materials}

Sheep erythrocytes were purchased from MP Biomedicals, LLC. Anti-sheep-erythrocyte-IgM was purchased from Rockland Incorporated. Sheep erythrocytes were incubated with antibody at $30^{\circ} \mathrm{C}$ to generate antibody-sensitized cells (EA), as previously described [23]. All antibody-sensitization was performed at $30^{\circ} \mathrm{C}$. Standard complement buffers were prepared for hemolytic assays: $\mathrm{GVBS}^{++}$(Veronal buffered saline, $0.1 \%$ gelatin, $0.15 \mathrm{mM} \mathrm{CaCl}_{2}$, and $1.0 \mathrm{mM} \mathrm{MgCl}_{2}$ ), Mg-EGTA-GVBS (Veronal buffered saline with $5 \mathrm{mM}$ $\mathrm{MgCl}_{2}$ and $8 \mathrm{mM}$ EGTA), and GVBS ${ }^{-}$(Veronal buffered saline, $0.1 \%$ gelatin, $0.01 \mathrm{M}$ EDTA), Veronal Buffered Saline (10 mM Barbital, $145 \mathrm{mM} \mathrm{NaCl}, \mathrm{pH}$ 7.4). Peptide Inhibitor of Complement C1 (PIC1) version AcPA, described elsewhere [24], was synthesized by New England Peptide (Gardner, MA). Lyophilized PIC1 was reconstituted in DMSO. Pooled normal human serum (NHS) was prepared as previously described [25]. C8-depleted human serum and purified C1q were purchased from CompTech (Tyler, TX).

\section{Hemolytic assays}

Antibody-initiated complement hemolytic assays were performed by incubating $100 \mu \mathrm{L}$ EA with $0.2 \%$ NHS in $\mathrm{GVBS}^{++}$. Hemolytic assays were performed for one hour at temperatures ranging from $0^{\circ} \mathrm{C}$ to $37^{\circ} \mathrm{C}$. A separate assay was performed with more clinically relevant temperatures of $31^{\circ}, 33^{\circ}, 35^{\circ}, 37^{\circ}, 39^{\circ}$, and $41^{\circ} \mathrm{C}$. EA were also incubated with water or buffer as controls. Hemolysis reactions were quenched with $4 \mathrm{~mL} \mathrm{GVBS}^{--}$and the supernatants recovered after sedimentation. Hemolysis was quantified by spectrophotometry of the supernatants at $412 \mathrm{~nm}$ and normalized as previously described [23]. Alternative complement pathway hemolytic assays were performed by incubating rabbit erythrocytes (CompTech, Tyler, TX) with $4 \%$ NHS in Mg-EGTA-GVBS at temperatures ranging from $0^{\circ} \mathrm{C}$ to $37^{\circ} \mathrm{C}$. A separate assay was performed with more clinically relevant temperatures of $31^{\circ}, 33^{\circ}, 35^{\circ}, 37^{\circ}, 39^{\circ}$, and $41^{\circ} \mathrm{C}$. Reactions were quenched with $2 \mathrm{~mL} \mathrm{GVBS}^{-}$, sedimented and measured as above.

\section{C5a ELISA}

Samples were generated by incubating $1 \%$ NHS with $400 \mu \mathrm{g} / \mathrm{ml}$ heat-aggregated IgG in $\mathrm{GVBS}^{++}$at each temperature for one hour. Heat-aggregated IgG was generated from purified human IgG (Gammagard, Baxter) as described elsewhere [23]. The reaction was stopped with EDTA-GVBS ${ }^{-}$and the samples were measured by C5a ELISA (R\&D Systems). Background values from controls of NHS and heat-aggregated human IgG incubated on ice for one hour were subtracted. 


\section{$\mathrm{C} 3$ and $\mathrm{C} 4$ assays}

$\mathrm{C} 3 / \mathrm{C} 4$ samples were generated by incubating C8-deficient serum (to prevent hemolysis), $1 \%$ final, with $0.25 \mathrm{~mL}$ EA in a total of $0.75 \mathrm{~mL}$ of $\mathrm{GVBS}^{++}$for one hour at each temperature. After incubation, the samples were washed twice with water to remove hemoglobin, and the resulting membrane bound $\mathrm{C} 3 / \mathrm{C} 4$ was stripped using $25 \mathrm{mM}$ methylamine. These samples were quantitated by total C3 ELISA, iC3b ELISA, and C4 ELISA as previously described [26]. C3 and C4 Western blot analysis was performed as described elsewhere [26].

\section{C1s western blot}

A Western blot to assess C1s activation by heat aggregated IgG has been previously described $[27,28]$ One microliter of partially purified $\mathrm{C} 1(0.2 \mathrm{mg} / \mathrm{ml}$, Complement Technologies, Inc.), $5 \mu \mathrm{l}$ of heat-aggregated IgG (1:250 dilution from $50 \mu \mathrm{g} / \mathrm{ml}$ stock), and $5 \mu \mathrm{l}$ of PBS were combined on ice and samples incubated at the following temperatures: $31,33,35,37,39$ and $41^{\circ} \mathrm{C}$ for 0 , 30, 45, 60 and 90 minutes. After incubation, $4 \mu \mathrm{l}$ of loading buffer was added and each sample was boiled. Gel electrophoresis on a $10 \%$ SDS-PAGE gel was performed at $140 \mathrm{~V}$ for 60 minutes. The gel was then transferred to a nitrocellulose membrane at $200 \mathrm{~mA}$ for 60 minutes. The membrane was washed twice for five minutes in PBS buffer and then blocked overnight in 5\% NFDMPBS. The next day, the membrane was probed with primary antibody, Goat anti-C1s (Quidel), at a dilution of 1:2000 in 5\% NFDM-PBS/0.1\% Tween-20 for one hour at room temperature. The membrane was washed $3 \mathrm{X}$ for 10 minutes with PBS $/ 0.1 \%$ Tween-20. Then, the membrane was probed with secondary antibody, Donkey anti-goat IR680 (Li-cor Biosciences), at a dilution of $1: 10,000$ in 5\% NFDM-PBS/0.1\% Tween-20 for one hour at room temperature. After washing the membrane $3 \mathrm{X}$ with $\mathrm{PBS} / 0.1 \%$ Tween-20, it was imaged on an Odyssey imager to determine the amounts of the C1s heavy and light chains characteristic of activated $\mathrm{C} 1 \mathrm{~s}$ relative to the proenzyme species.

\section{C1/C1q binding}

C1 either from NHS (0.33\% final) or C8-deficient serum (CompTech), or purified C1q (Comp Tech) at $0.24 \mu \mathrm{g} /$ $\mathrm{ml}$ final, was combined with $100 \mu \mathrm{l}$ of sensitized sheep erythrocytes in a total volume of $0.75 \mathrm{ml}$ of GVBS++ for one hour at the various temperatures. These cells were then washed twice with water and the resulting cell pellet was dissolved with $0.5 \%$ NP40. Membrane bound C1q was analyzed by a quantitative Dot Blot assay. Pure C1q was titrated onto PVDF membrane, along with the samples, via a Dot Blot apparatus. The membrane was blocked with $3 \%$ BSA, probed with a goat anti-C1q antibody (Comp Tech), and then an HRP-labeled rabbit anti-goat secondary antibody (Sigma-Aldrich). Bound antibody was detected by enhanced chemiluminescence. Using the Quantity One software (Bio-Rad), grey scale values were assigned to the pure $\mathrm{C} 1 \mathrm{q}$ titration and the samples so that a linear regression could be used to quantify the amount of $\mathrm{C} 1 \mathrm{q}$ in each sample.

\section{PIC1 inhibition of cold-enhanced complement activation}

Peptide Inhibitors of complement C1 (PIC1) specifically inhibit $\mathrm{C} 1$ activation, as previously described [24,28]. Here we use the AcPA form (IALILEPICCQERAA) [24] of PIC1. Preparations of $16.5 \%$ normal human serum (NHS) in $\mathrm{GVBS}^{++}$were incubated with $0.98 \mathrm{mM}, 0.82 \mathrm{mM}$, $0.65 \mathrm{mM}, 0.48 \mathrm{mM}$ or $0.32 \mathrm{mM}$ PIC1, DMSO vehicle control, or buffer control at $4^{\circ} \mathrm{C}$ for 1 hour. Samples were further diluted 1:10 in $\mathrm{GVBS}^{++}$. Hemolysis reactions were then performed with $100 \mu \mathrm{L}$ of NHS sample plus $550 \mu \mathrm{L}$ of additional $\mathrm{GVBS}^{++}$and $100 \mu \mathrm{L}$ of EA over 1 hour at either in $31^{\circ}$ or $37^{\circ} \mathrm{C}$. Controls and samples were processed and measured by spectrophotometry at $412 \mathrm{~nm}$.

\section{Statistical analysis}

Means and standard error of the means (SEM) were calculated from independent experiments. Statistical comparisons were made using one way ANOVA and Student's $t$-test where appropriate. Statistical analysis was performed using GraphPad InStat 3 software.

\section{Results}

Functional hemolytic assays of complement activation at hypothermic temperatures

In order to evaluate antibody-initiated complementactivation at therapeutic hypothermia temperatures, we tested antibody-sensitized sheep erythrocytes (EA) incubated in normal human serum at $31^{\circ} \mathrm{C}-41^{\circ} \mathrm{C}$ and measured hemolysis. In this CH50-type assay, hemolysis of antibodysensitized erythrocytes in human serum differed significantly as a function of temperature (ANOVA $\mathrm{P}<0.01$ ). There was 9-fold more hemolysis at $31^{\circ} \mathrm{C}$ compared with $41^{\circ} \mathrm{C}(t$-test $\mathrm{P}<0.01)$ and 2 fold more hemolysis at $31^{\circ} \mathrm{C}$ compared with $37^{\circ} \mathrm{C}(t$-test $\mathrm{P}=0.01)$ (Figure $\left.1 \mathrm{~A}\right)$. These results show that antibody-initiated complement activation increased at therapeutic hypothermia temperatures. Given that complement activation is severely inhibited at near $0^{\circ} \mathrm{C}$ temperatures, we then evaluated complement activation for temperatures ranging from $0^{\circ} \mathrm{C}-37^{\circ} \mathrm{C}$. Antibody-initiated complement activation in human serum increased as temperature decreased from $37^{\circ} \mathrm{C}$ to $24^{\circ} \mathrm{C}$ until dramatically decreasing at $13^{\circ} \mathrm{C}$ (Figure 1B). In these assays a similar 2-fold increase in antibody-initiated complement activation was noted comparing $31^{\circ} \mathrm{C}$ with $37^{\circ} \mathrm{C}(t$-test $\mathrm{P}<0.01)$. From $0^{\circ} \mathrm{C}-13^{\circ} \mathrm{C}$ complement activation was minimal.

We then tested whether similar effects would be observed for the alternative complement pathway over 


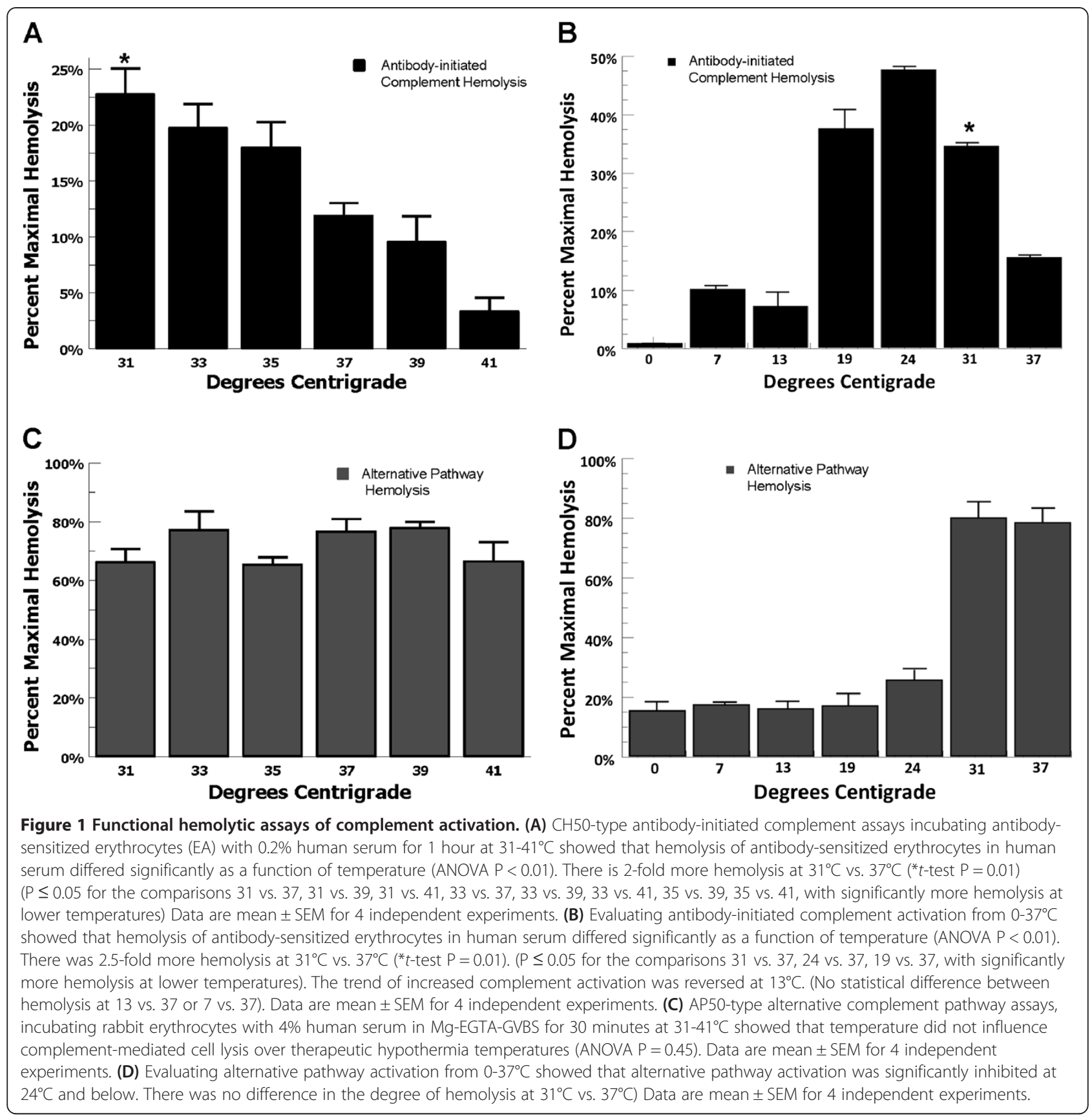

therapeutic hypothermia temperatures. In an AP50-type alternative complement pathway assay, temperature did not alter complement-mediated cell lysis at therapeutic hypothermia temperatures (ANOVA P $=0.45$ ) (Figure $1 \mathrm{C}$ ). Testing alternative pathway activation from $0^{\circ} \mathrm{C}-37^{\circ} \mathrm{C}$ demonstrated that activation was significantly inhibited at $24^{\circ} \mathrm{C}$ and below (Figure 1D). These results show that antibody-initiated complement activation increased at clinical hypothermia temperatures compared with euthermia, suggesting that antibody-initiated complement activation occurring during reperfusion at hypothermic temperatures could potentially increase complement-mediated tissue damage.

\section{Complement cascade activation assays}

Complement-mediated hemolysis results from pores generated by the membrane attack complex (MAC), suggesting that increased terminal complement cascade activation was occurring at lower temperatures. In order to further evaluate activation of the terminal complement cascade we measured $\mathrm{C} 5 \mathrm{a}$ generation in response to a different antibody-initiated complement activator, 
heat-aggregated IgG. C5a is also an extremely potent anaphylatoxin important for phagocytic cell recruitment and activation [29] and implicated in contributing to tissue damage in many inflammatory diseases processes [30]. Heat-aggregated IgG incubated with normal human serum demonstrated that C5a generation differed significantly as a function of temperature (ANOVA $\mathrm{P}<0.01$ ). There was a $>2$-fold increase in $\mathrm{C} 5 \mathrm{a}$ generation at $31^{\circ} \mathrm{C}$ compared with $37^{\circ} \mathrm{C}(t$-test $\mathrm{P}=0.05)$ (Figure $\left.2 \mathrm{~A}\right)$. These data show that at clinical hypothermia temperatures terminal complement cascade activation increased, consistent with the CH50-type assay, and suggests that increased C5a

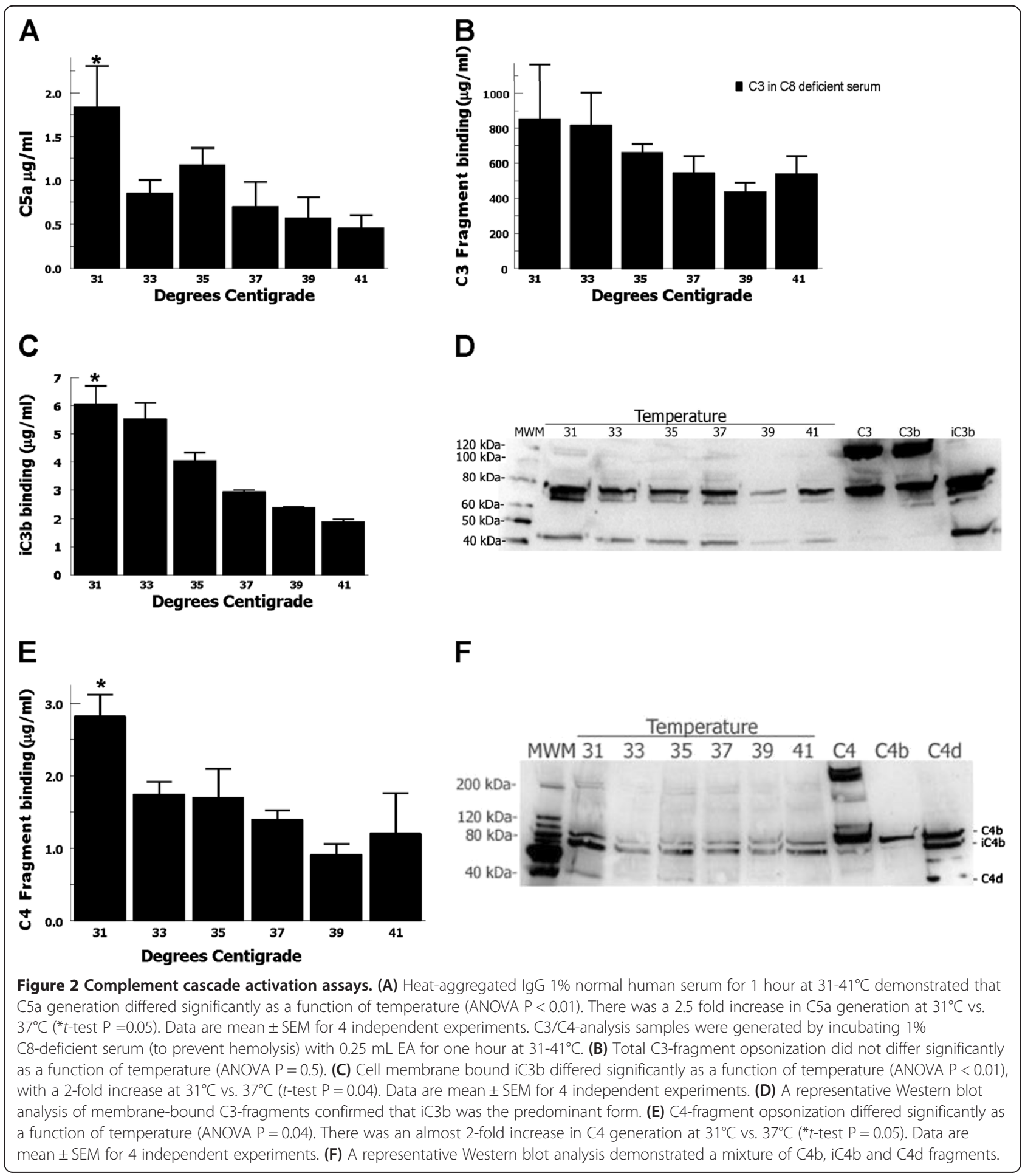


generation at these temperatures could increase neutrophil recruitment and activation enhancing inflammation and host tissue damage during reperfusion.

C3 is the central component of the complement cascades and its activation results in generation of the anaphylatoxin $\mathrm{C} 3 \mathrm{a}$ and opsonization of targets with the C3-fragments, C3b and iC3b. We tested C3 activation and opsonization with $\mathrm{C} 3 \mathrm{~b} / \mathrm{iC} 3 \mathrm{~b}$ by incubating EA with $\mathrm{C} 8$ deficient serum (to prevent hemolysis). Though total C3fragment opsonization as a function of temperature was not statistically significant (ANOVA $\mathrm{P}=0.5$ ) (Figure $2 \mathrm{~B}$ ), cell membrane bound $\mathrm{iC} 3 \mathrm{~b}$ differed significantly as a function of temperature (ANOVA $\mathrm{P}<0.01$ ), with a 2 -fold increase at $31^{\circ} \mathrm{C}$ versus $37^{\circ} \mathrm{C}(t$-test $\mathrm{P}=0.04)$ (Figure $2 \mathrm{C}$ ). Western blot analysis of membrane-bound C3-fragments confirmed that $\mathrm{iC} 3 \mathrm{~b}$ was the predominant form and suggested increased $\mathrm{iC} 3 \mathrm{~b}$ deposition at lower temperatures (Figure 2D) consistent with ELISA data. These data show that $\mathrm{C} 3$ activation and $\mathrm{iC} 3 \mathrm{~b}$ opsonization increased at clinical hypothermia temperatures, suggesting that these temperatures could increase opsonization of host cells (e.g. endothelial cells) during reperfusion targeting them for phagocyte attack.

In order to specifically evaluate the classical complement pathway, we tested $\mathrm{C} 4$ activation by incubating EA with C8-deficient serum. C4-fragment binding differed significantly as a function of temperature (ANOVA $\mathrm{P}=0.04$ ). There was an almost 2-fold increase in $\mathrm{C} 4$ generation at $31^{\circ} \mathrm{C}$ compared with $37^{\circ} \mathrm{C}(t$-test $\mathrm{P}=0.05)$ (Figure $2 \mathrm{E}$ ). Western blot analysis demonstrated a mixture of $\mathrm{C} 4 \mathrm{~b}$, iC4b and C4d fragments (Figure $2 \mathrm{~F}$ ) and suggested increased C4-fragment binding at $31^{\circ} \mathrm{C}$. These findings show that classical pathway activation is increased at therapeutic hypothermia temperatures and suggests that $\mathrm{C} 1$ activation, which cleaves $\mathrm{C} 4$, is also increased at these temperatures.

\section{C1 activation and binding}

$\mathrm{C} 1$ is a complex molecule consisting of a pattern (e.g., IgG/M) recognition component $\mathrm{Clq}$, which associates with the serine protease tetramer $\mathrm{C} 1 \mathrm{r}-\mathrm{C} 1 \mathrm{~s}-\mathrm{C} 1 \mathrm{~s}-\mathrm{C} 1 \mathrm{r}$. When the $\mathrm{C} 1 \mathrm{q}$ portion of the molecule binds to $\mathrm{IgG} / \mathrm{M}$, it causes auto-activation of the enzymatic tetramer leading to activation of $\mathrm{C} 4$ and the classical pathway cascade. Therefore, increased activation of $\mathrm{C} 1$ at lower temperatures could be caused by increased $\mathrm{C} 1 \mathrm{q}$ binding, or increased enzymatic activity, or both. $\mathrm{C} 1$ enzymatic activation was tested at increasing temperatures over a 90 minute period using heataggregated IgG incubated with partially purified C1. C1s activation was assayed by the conversion of precursor $\mathrm{C} 1 \mathrm{~s}$ to its activated heavy and light chain forms, as previously described [27,28]. C1s activation decreased at therapeutic hypothermia temperatures, suggesting decreased enzymatic activity at lower temperatures (Figure 3).

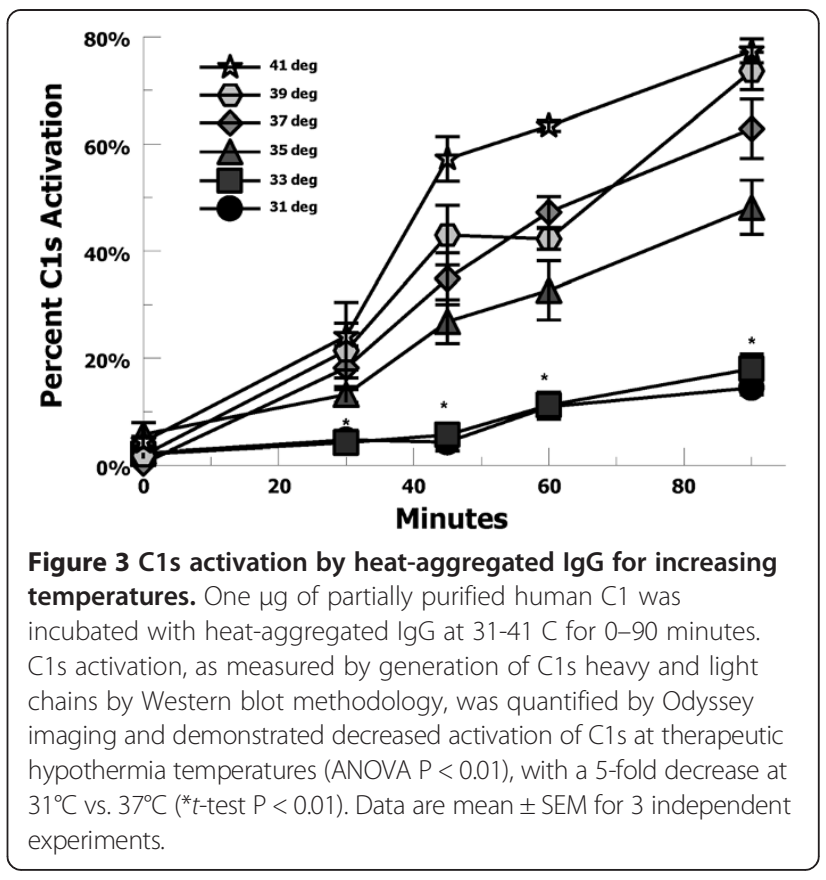

$\mathrm{C} 1 \mathrm{q}$ and $\mathrm{C} 1$ binding was tested by incubating EA with purified C1q, or normal human serum, or C8-deficient serum. In each case, $\mathrm{C} 1 / \mathrm{C} 1 \mathrm{q}$ binding to EA showed a consistent trend of increasing at lower temperatures (Figures 4A, $\mathrm{B}$, and $\mathrm{C}$ ), suggesting that increased classical complement pathway activation is likely mediated by increased $\mathrm{C} 1$ binding at therapeutic hypothermia temperatures. These findings may also explain the lack of hypothermia-enhanced alternative pathway activation where initiation is not mediated by a pattern recognition molecule (e.g. C1q) binding event.

\section{Inhibition of C1-mediated complement activation}

In order to further elucidate the role of $\mathrm{C} 1$ in antibodyinitiated hypothermia-enhanced complement activation, we tested a specific inhibitor of $\mathrm{C} 1$ activation, PIC1, (Peptide Inhibitor of complement C1) $[23,24,27,28]$. In the CH50-type assay, PIC1 successfully inhibited hypothermia-enhanced complement activation at $31^{\circ} \mathrm{C}$ in a dose-dependent manner by up to $60 \%$ compared with untreated control (ANOVA $\mathrm{P}=<0.01$ ) (Figure 5). At $0.98 \mathrm{mM} \mathrm{PIC1}$ inhibited hypothermia-enhanced $\left(31^{\circ} \mathrm{C}\right)$ complement-mediated cell lysis to a level not statistically different from that for euthermia $\left(37^{\circ} \mathrm{C}\right)(t$-test $\mathrm{P}=0.44)$. These results suggest that hypothermia-enhanced antibody-initiated complement activation can be blocked using a specific inhibitor of $\mathrm{C} 1$ activation.

\section{Discussion}

The clinical benefit of therapeutic hypothermia in moderating IRI and improving neurological outcomes is modest, but clear [31,32]. Therapeutic hypothermia offers an 11\% reduction in risk of death or disability in neonatal hypoxic 

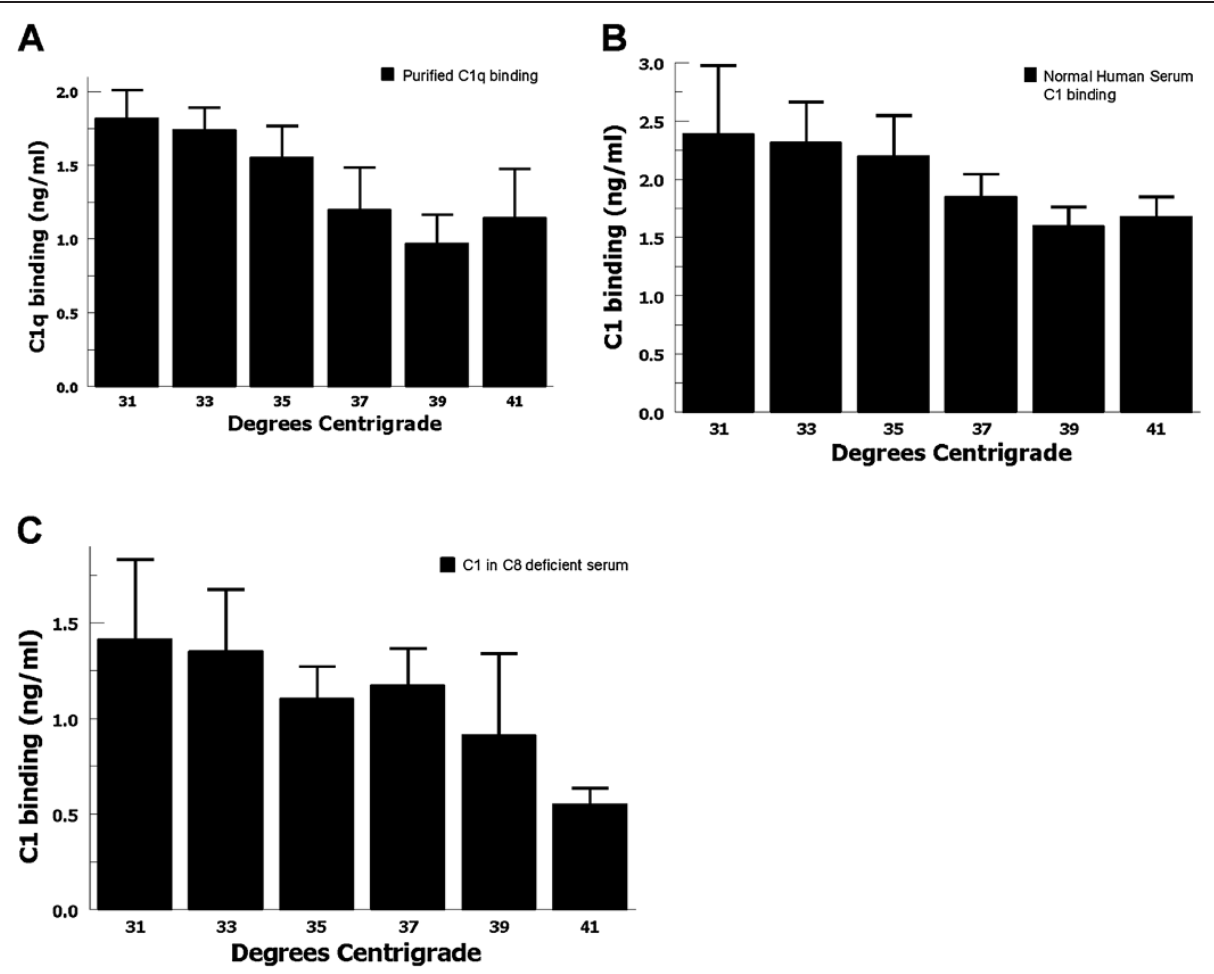

Figure $4 \mathrm{C} 1 / \mathrm{C} 1 \mathrm{q}$ binding at therapeutic hypothermia temperatures. $\mathrm{C} 1 \mathrm{q}$ binding was tested by incubating antibody-sensitized erythrocytes with (A) purified C1q, (B) normal human serum, or (C) C8-deficient serum for one hour at $31-41^{\circ} \mathrm{C}$. In each case, there was a consistent trend of increased $\mathrm{C} 1 \mathrm{q}$ binding to EA at lower temperatures. Data are mean \pm SEM for 4 independent experiments.

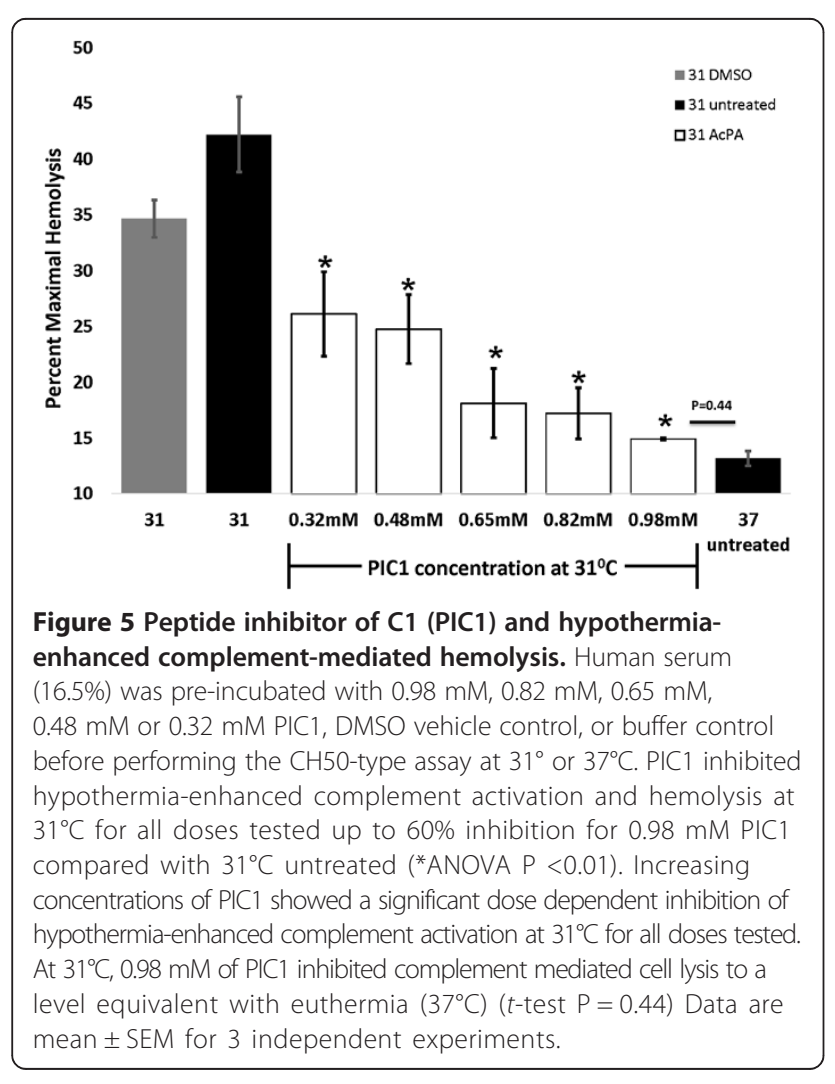

ischemic brain injury, a decrease from $58 \%$ to $47 \%$ [33]. Therapeutic hypothermia appears to have beneficial effects for several mechanisms that likely contribute to the pathogenesis of IRI, but all of the effects of cooling the human body are unknown. It is reasonable to expect that a nontargeted treatment such as therapeutic hypothermia may have some unrecognized detrimental actions, which could partially attenuate the positive effects. The most striking finding from our studies is that therapeutic hypothermia temperatures increase antibody-initiated complement activation enhancing inflammation, opsonization, and destruction of eukaryotic cells in vitro. Thus, our data strongly suggests that the therapeutic effect of hypothermia may not be mediated by reducing complement activation, but rather, clinical benefit is derived via other mechanisms. These data suggest that therapeutic hypothermia temperatures likely increase antibody-initiated complement activation in vivo (Figure 6), potentially partially attenuating the clinical benefits of therapeutic hypothermia in the treatment of IRI.

Our data show that increased complement activation at lower temperatures was mediated by antibody-initiated complement activation, but the alternative pathway was unaffected by the temperatures tested. Therapeutic hypothermia temperatures increased complement-mediated cell lysis demonstrating enhanced membrane attack complex 


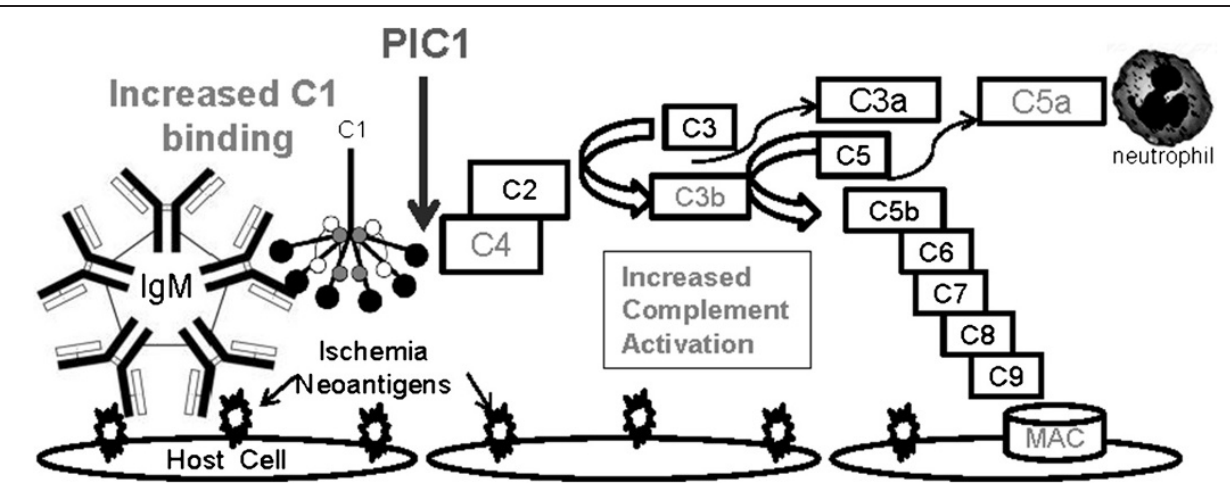

Figure 6 Model of antibody-initiated complement activation in ischemia reperfusion injury and hypothermia effects on complement activation. Hypoxic insult induces expression of 'neoantigens' on the surface of vascular endothelial cells. These neoantigens are recognized by natural antibodies (IgM) initiating complement activation leading to downstream inflammatory effectors. Therapeutic hypothermia temperatures were shown to increase C1/C1q binding, increase opsonization with C4-fragments and C3-fragments, increase C5a anaphylatoxin generation, and increase eukaryotic cell lysis via membrane attack complex (MAC) formation. Increases in complement function demonstrated in this study are shown in grey. PIC1 inhibits complement activation at C1 preventing C4 activation.

pore formation. At lower temperatures there was increased C5a generation, which recruits and activates neutrophils enhancing local inflammation. Increased iC3b opsonization of eukaryotic cells occurred at lower temperatures, which targets them for attack by phagocytic cells. Increased C4 activation at low temperatures suggested increased activation at $\mathrm{C} 1$, which cleaves $\mathrm{C} 4$. Testing activation of the enzymatic components of $\mathrm{C} 1$ showed decreased enzymatic activity at lower temperatures, which is a common property of enzymatic reactions. However, multiple assays testing $\mathrm{C} 1$ or C1q binding showed a consistent trend toward increased binding to antibody-sensitized cells at lower temperatures. Increased binding of molecules often occurs at lower temperatures [34] and suggested that increased binding of $\mathrm{C} 1$ may be responsible for increased antibody-initiated complement activation despite decreased enzymatic activity. Increased antibody-initiated complement activation was not mediated by temperature effects on antibody-binding, because all antibody-sensitization procedures were performed at $30^{\circ} \mathrm{C}$. Using serum from a patient with cutaneous vasculitis, it was found that cryoglobulin increased activation of the complement system at $20^{\circ} \mathrm{C}$ [35].

It is notable that antibody-initiated complement activation was decreased at $41^{\circ} \mathrm{C}$ compared with $37^{\circ} \mathrm{C}$. We speculate that decreased antibody-initiated complement activation at febrile temperatures may be a mechanism of dampening classical pathway activation after systemic inflammation with cytokines and TNF has been achieved. Classical pathway activation occurs extremely early in inflammation and once initiated, complement activation will be perpetuated by the positive-feedback loop of the alternative pathway, which does not appear to be affected by febrile temperatures. Thus, this may be a down-regulatory mechanism to decrease further activation of the classical pathway and moderating potential complement-mediated damage to the host. Although mechanistically different, fever decreasing classical pathway activation may be functionally similar to soluble TNF-receptor generation downregulating TNF effects late in inflammation [36,37].

In order to elucidate the mechanism of hypothermiaenhanced antibody-initiated complement activation, we tested a specific inhibitor of $\mathrm{C} 1$ activation (Figure 6). PIC1 successfully inhibited hypothermia-enhanced complement activation at $31^{\circ} \mathrm{C}$ to a level similar to that which occurred at euthermia $\left(37^{\circ} \mathrm{C}\right)$, consistent with $\mathrm{C} 1$ mediated activation.

Our findings differ from a study demonstrating attenuated complement activation following hypothermia in vivo in a cohort of cardiopulmonary bypass patients [38]. However, the findings in the study cannot be attributed to hypothermia alone, since the practices of hemodilution and heparinization in cardiopulmonary bypass utilized in this study likely confound the association as they are independent causes of complement inhibition [39]. One of the limitations of this study is that it does not model IRI. However, this limitation allowed us to explore the independent effect of hypothermia on antibody-initiated complement activation. Future directions include testing the effects of hypothermia in the Vannucci model of rat brain IRI [40] and elucidating the contribution of the lectin and classical pathway in hypothermia enhanced complement activation.

\section{Conclusions}

Therapeutic hypothermia temperatures increased antibodyinitiated complement activation and eukaryotic cell destruction suggesting that the benefits of therapeutic hypothermia may be mediated via other mechanisms. A peptide inhibitor of complement (PIC1) significantly inhibited this enhanced complement activation. Antibody-initiated complement 
activation has been shown to contribute to ischemiareperfusion injury in several animal models, suggesting that for diseases with this mechanism hypothermia-enhanced complement activation may partially attenuate the benefits of therapeutic hypothermia. Future directions include testing the relationship between complement activation and hypothermia in an animal model of neonatal hypoxicischemic encephalopathy.

\section{Competing interests}

The authors have no conflicts of interest or financial disclosures to report with regard to this manuscript. PIC1 and its derivatives are currently protected under US Patent 8,241,843 and Patent Pending 13/809371.

\section{Authors' contributions}

Conceived the ideas for this study NKK, KMC; Acquisition, analysis and interpretation of data TAS, CTM, PSH, AS, MPS, WTB, NKK, KMC; Wrote the manuscript TAS, NKK, KMC; All authors read and approved the final manuscript.

\section{Acknowledgements}

This work was supported by a grant from NIH (R21Al095750) awarded to Dr. Krishna.

\section{Author details}

'Department of Pediatrics, Eastern Virginia Medical School, 855 West Brambleton Avenue, Norfolk, VA 23510, USA. ²Department of Microbiology and Molecular Cell Biology, Eastern Virginia Medical School, 700 West Olney Road, Norfolk, VA 23507-1696, USA. ${ }^{3}$ Children's Specialty Group, 811 Redgate Avenue, Norfolk, VA 23507, USA. ${ }^{4}$ Children's Hospital of The King's Daughters, 601 Children's Lane, Norfolk, VA 23507, USA.

Received: 11 December 2013 Accepted: 16 June 2014 Published: 24 June 2014

\section{References}

1. Group HCAS: Mild therapeutic hypothermia to improve the neurologic outcome after cardiac arrest. N Engl J Med 2002, 346:549-556.

2. BT Foundation, Surgeons AAoN, Surgeons CoN: Guidelines for the management of severe traumatic brain injury. J Neurotrauma 2007, 24(Suppl 1):S1-106.

3. Yenari MA, Hemmen TM: Therapeutic hypothermia for brain ischemia: where have we come and where do we go? Stroke 2010, 41:S72-74.

4. Stravitz RT, Larsen FS: Therapeutic hypothermia for acute liver failure. Crit Care Med 2009, 37:S258-264.

5. Shankaran S, Laptook AR, Ehrenkranz RA, Tyson JE, McDonald SA, Donovan EF, Fanaroff AA, Poole WK, Wright LL, Higgins RD, Finer NN, Carlo WA, Duara S, Oh W, Cotten CM, Stevenson DK, Stoll BJ, Lemons JA, Guillet R, Jobe AH: Whole-body hypothermia for neonates with hypoxic-ischemic encephalopathy. N Engl J Med 2005, 353:1574-1584.

6. Erecinska $M$, Thoresen M, Silver IA: Effects of hypothermia on energy metabolism in Mammalian central nervous system. J Cereb Blood Flow Metab 2003, 23:513-530.

7. Kimura A, Sakurada S, Ohkuni H, Todome Y, Kurata K: Moderate hypothermia delays proinflammatory cytokine production of human peripheral blood mononuclear cells. Crit Care Med 2002, 30:1499-1502.

8. Polderman $\mathrm{KH}$ : Mechanisms of action, physiological effects, and complications of hypothermia. Crit Care Med 2009, 37:S186-202.

9. Ning XH, Chen SH, Xu CS, Li L, Yao LY, Qian K, Krueger JJ, Hyyti OM, Portman MA: Hypothermic protection of the ischemic heart via alterations in apoptotic pathways as assessed by gene array analysis. J Appl Physiol 2002, 92:2200-2207.

10. Xu L, Yenari MA, Steinberg GK, Giffard RG: Mild hypothermia reduces apoptosis of mouse neurons in vitro early in the cascade. $J$ Cereb Blood Flow Metab 2002, 22:21-28.

11. Globus MY, Busto $R$, Lin B, Schnippering $H$, Ginsberg MD: Detection of free radical activity during transient global ischemia and recirculation: effects of intraischemic brain temperature modulation. J Neurochem 1995 , 65:1250-1256.
12. Karkar KM, Garcia PA, Bateman LM, Smyth MD, Barbaro NM, Berger M: Focal cooling suppresses spontaneous epileptiform activity without changing the cortical motor threshold. Epilepsia 2002, 43:932-935

13. Huang ZG, Xue D, Preston E, Karbalai H, Buchan AM: Biphasic opening of the blood-brain barrier following transient focal ischemia: effects of hypothermia. Can J Neurol Sci 1999, 26:298-304.

14. Schaller B, Graf R: Hypothermia and stroke: the pathophysiological background. Pathophysiology 2003, 10:7-35.

15. Mastellos D, Morikis D, Isaacs SN, Holland MC, Strey CW, Lambris JD: Complement: structure, functions, evolution, and viral molecular mimicry. Immunol Res 2003, 27:367-386.

16. Elvington A, Atkinson C, Kulik L, Zhu H, Yu J, Kindy MS, Holers VM, Tomlinson S: Pathogenic natural antibodies propagate cerebral injury following ischemic stroke in mice. J Immuno/ 2012, 188:1460-1468.

17. Chan RK, Ibrahim SI, Verna N, Carroll M, Moore FD, Hechtman HB: Ischaemia-reperfusion is an event triggered by immune complexes and complement. Br J Surg 2003, 90:1470-1478.

18. Elvington A, Atkinson C, Zhu H, Yu J, Takahashi K, Stahl GL, Kindy MS, Tomlinson S: The alternative complement pathway propagates inflammation and injury in murine ischemic stroke. J Immunol 2012, 189:4640-4647.

19. Miwa T, Sato S, Gullipalli D, Nangaku M, Song WC: Blocking properdin, the alternative pathway, and anaphylatoxin receptors ameliorates renal ischemia-reperfusion injury in decay-accelerating factor and CD59 double-knockout mice. J Immunol 2013, 190:3552-3559.

20. He S, Atkinson C, Qiao F, Cianflone K, Chen X, Tomlinson S: A complementdependent balance between hepatic ischemia/reperfusion injury and liver regeneration in mice. J Clin Invest 2009, 119:2304-2316.

21. Bouma HR, Carey HV, Kroese FG: Hibernation: the immune system at rest? J Leukoc Biol 2010, 88:619-624.

22. Mollnes TE, Garred P, Bergseth G: Effect of time, temperature and anticoagulants on in vitro complement activation: consequences for collection and preservation of samples to be examined for complement activation. Clin Exp Immunol 1988, 73:484-488.

23. Bonaparte RS, Hair PS, Banthia D, Marshall DM, Cunnion KM, Krishna NK: Human astrovirus coat protein inhibits serum complement activation via C1, the first component of the classical pathway. J Virol 2008, 82:817-827.

24. Mauriello CT, Pallera HK, Sharp JA, Woltmann JL, Oian S, Hair PS, van der Pol $P$, van Kooten C, Thielens NM, Lattanzio FA, Cunnion KM, Krishna NK: A novel peptide inhibitor of classical and lectin complement activation including ABO incompatibility. Mol Immunol 2013, 53:132-139.

25. Cunnion KM, Lee JC, Frank MM: Capsule production and growth phase influence binding of complement to Staphylococcus aureus. Infect Immun 2001, 69:6796-6803.

26. Hair PS, Echague CG, Rohn RD, Krishna NK, Nyalwidhe JO, Cunnion KM: Hyperglycemic conditions inhibit C3-mediated immunologic control of Staphylococcus aureus. J Transl Med 2012, 10:35.

27. Hair PS, Gronemus JQ, Crawford KB, Salvi VP, Cunnion KM, Thielens NM, Arlaud GJ, Rawal N, Krishna NK: Human astrovirus coat protein binds C19 and MBL and inhibits the classical and lectin pathways of complement activation. Mol Immunol 2010, 47:792-798.

28. Gronemus JQ, Hair PS, Crawford KB, Nyalwidhe JO, Cunnion KM, Krishna NK: Potent inhibition of the classical pathway of complement by a novel C1q-binding peptide derived from the human astrovirus coat protein Mol Immunol 2010, 48:305-313.

29. Serruto D, Rappuoli R, Scarselli M, Gros P, van Strijp JA: Molecular mechanisms of complement evasion: learning from staphylococci and meningococci. Nat Rev Microbiol 2010, 8:393-399.

30. Guo RF, Ward PA: Role of C5a in inflammatory responses. Annu Rev Immunol 2005, 23:821-852

31. Gonzalez-Ibarra FP, Varon J, Lopez-Meza EG: Therapeutic hypothermia: critical review of the molecular mechanisms of action. Front Neurol 2011, 2:4.

32. Moore EM, Nichol AD, Bernard SA, Bellomo R: Therapeutic hypothermia: benefits, mechanisms and potential clinical applications in neurological, cardiac and kidney injury. Injury 2011, 42:843-854

33. Robertson NJ, Tan S, Groenendaal F, van Bel F, Juul SE, Bennet L, Derrick M, Back SA, Valdez RC, Northington F, Gunn AJ, Mallard C: Which neuroprotective agents are ready for bench to bedside translation in the newborn infant? J Pediatr 2012, 160:544-552.e544.

34. Kodama H, Kodama Y, Shinozawa S, Kanemaru R, Todaka K, Mitsuyama Y: Temperature effect on serum protein binding kinetics of phenytoin in 
monotherapy patients with epilepsy. Eur J Pharm Biopharm 1999, 47:295-298.

35. Muller S, Rother U, Westerhausen M: Complement activation by cryoglobulin. Evidence for a pathogenic role of an IgG (kappa) cryoglobulin in cutaneous vasculitis. Clin Exp Immunol 1976, 23:233-241.

36. Moon R, Pritts TA, Parikh AA, Fischer JE, Salzman AL, Ryan M, Wong HR, Hasselgren PO: Stress response decreases the interleukin-1 beta-induced production of complement component C3 in human intestinal epithelial cells. Clin Sci (Lond) 1999, 97:331-337.

37. Loetscher H, Steinmetz M, Lesslauer W: Tumor necrosis factor: receptors and inhibitors. Cancer Cells 1991, 3:221-226.

38. Moore FD, Warner KG, Assousa S, Valeri CR, Khuri SF: The effects of complement activation during cardiopulmonary bypass. Attenuation by hypothermia, heparin, and hemodilution. Ann Surg 1988, 208:95-103.

39. Bruins $P$, te Velthuis $H$, Eerenberg-Belmer AJ, Yazdanbakhsh AP de Beaumont EM, Eijsman L, Trouwborst A, Hack CE: Heparin-protamine complexes and $\mathrm{C}$-reactive protein induce activation of the classical complement pathway: studies in patients undergoing cardiac surgery and in vitro. Thromb Haemost 2000, 84:237-243.

40. Rice JE, Vannucci RC, Brierley JB: The influence of immaturity on hypoxicischemic brain damage in the rat. Ann Neurol 1981, 9:131-141.

doi:10.1186/1479-5876-12-181

Cite this article as: Shah et al: Clinical hypothermia temperatures increase complement activation and cell destruction via the classical pathway. Journal of Translational Medicine 2014 12:181.

\section{Submit your next manuscript to BioMed Central and take full advantage of:}

- Convenient online submission

- Thorough peer review

- No space constraints or color figure charges

- Immediate publication on acceptance

- Inclusion in PubMed, CAS, Scopus and Google Scholar

- Research which is freely available for redistribution 